\title{
ACRL honors the 2006 award winners A recognition of professional achievement
}

\section{ACRL Excellence in Academic Libraries winners announced}

The winners of the 2006 Excellence in Academic Libraries Award are the Thomas Tredway Library at Augustana College in Rock Island, Illinois, and the Rochester Institute of Technology Libraries in Rochester, New York. An award in the community college category was not made this year.

Sponsored by ACRL and Blackwell's Book Services, the award recognizes the staff of a college, university, and community college library for programs that deliver exemplary services and resources to further the educational mission of the institution.

"Receiving an Excellence in Academic Libraries Award is a national tribute to a library and its staff for the outstanding services, programs, and leadership they provide to their students, administrators, faculty and community," said Mary Ellen K. Davis, ACRL executive director.

\section{Thomas Tredway Library}

The Thomas Tredway Library at Augustana College, winner in the college category, demonstrated success at implementing innovative library programs in order to enhance its involvement with faculty and students on campus.

"The Tredway Library at Augustana College provides an impressive range of services, well beyond what would be expected by a library of its size and resources," said Julia Zimmerman, member of the 2006 Excellence in Academic Libraries Selection Committee.

"The staff have developed a number of exciting and often quite innovative collabo-

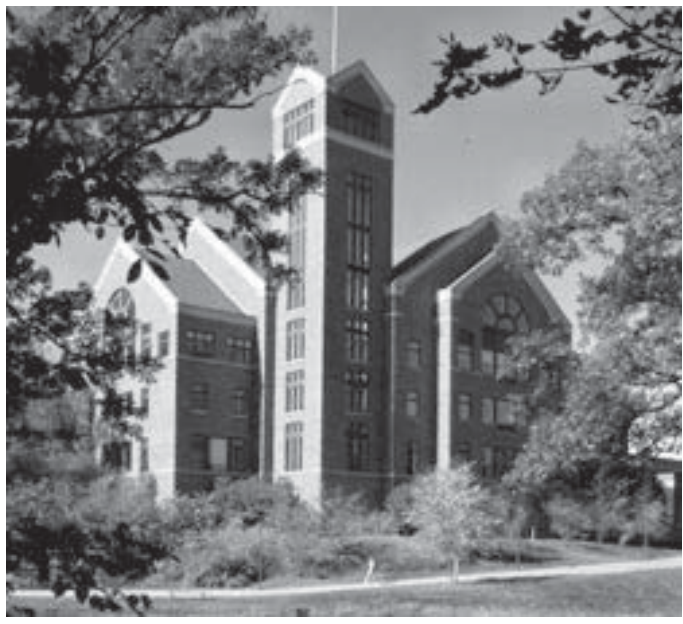

Thomas Tredway Library at Augustana College

rations with faculty, academic support units, and student groups. They are committed to accountability and assessment, with results that show that students and faculty place a very high value on the library as a vital contributor to academic life and 'the living room of the campus."”

\section{Rochester Institute of Technology Libraries}

The Rochester Institute of Technology Libraries is the winner in the university category and was selected for its impressive implementation of a new strategic planning process.

"Over the past few years, the RIT library system has reinvented itself from the ground up," said Zimmerman. "A very creative strategic planning process launched in 2004 involved the entire library staff, giving them responsibility for intensive outreach to campus

Megan Bielefeld is ACRL program coordinator, e-mail: mbielefeld@ala.org 


\section{English named Academic/Research Librarian of the Year}

Ray English, Azariah Smith Root director of libraries at Oberlin College in Oberlin, Ohio, is the 2006 ACRL Academic/Research Librarian of the Year. The award, sponsored by YBP Library Services, recognizes an outstanding member of the library profession who has made a significant national or international contribution to academic/research librarianship and library development.

"English's greatest impact as a librarian, perhaps, and the area of his work that stands out to the selection committee," said award committee chair Les Canterbury, "is his advocacy for open access to the results of scholarly research. He has been a primary leader of the ACRL scholarly communications program, has been active in the Scholarly Publishing and Academic Resources Coalition (SPARC), and has fostered close cooperation on scholarly communications issues among ACRL, SPARC, and the Association of Research Libraries. In addition,

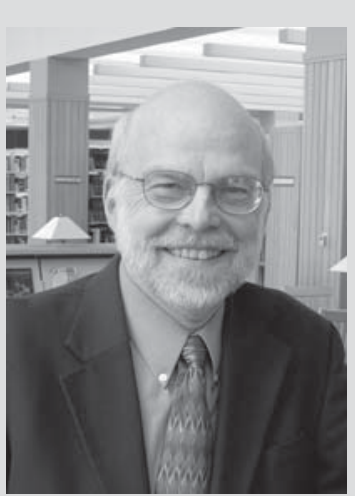

Ray English moving the change process forward. We need to make them familiar with the issues and encourage them to take action. We also need to support Congressional legislation that, if passed, will make a tremendous difference in public access to research. Please join in this critical work."

English is a founding member and chair of the ACRL Scholarly Communication Committee and was recently elected chair of the steering committee of SPARC, of which Oberlin College is a founding member. He has also lectured and written extensively on scholarly communication issues and open access. Since 1988, English has served on more than 15 ALA and ACRL committees and is a former ACRL Board member (1996-98).

Under English's leadership, Oberlin became the first private, liberal arts college library to join OhioLINK. In addition, he participated in a cooperative effort with four other Ohio private colleges in establishing a new and on a larger stage, he has influenced, as an expert contributor, national policy on public access to federally funded research, including the recent National Institutes of Health Public Access Policy."

"I was delighted when ACRL President Camila Alire called to tell about this award," said English. "It's a wonderful honor to be recognized by peers in this way. I'm especially grateful to those colleagues who put forward my nomination, including Deb Dancik, Bob Rose, and members of the ACRL Scholarly Communication Committee."

"I want to take the occasion of the award to encourage all academic librarians to become engaged with scholarly communications issues, both at the campus and the national level. We're seeing terrific progress on these issues, particularly in terms of open access. Faculty are key in consortium, the Five Colleges of Ohio, that received a major grant from the Andrew W. Mellon Foundation for library resource sharing. He also coordinated a $\$ 475,000$ grant from the Andrew W. Mellon Foundation to incorporate information literacy into the liberal arts curriculum of each Ohio Five school. In addition, English was co-project director of an Institute of Museum and Library Services National Leadership grant to create a library diversity intern program at Oberlin College from 2000 to 2002. The Oberlin College Library received the 2002 ACRL Excellence in Academic Libraries Award in the college category.

English will receive a $\$ 3,000$ award on Monday, June 26, 2006, at 4:30 p.m., at a Annual Conference in New Orleans. The reception is sponsored by YBP Library Services. ceremony and reception during the ALA 


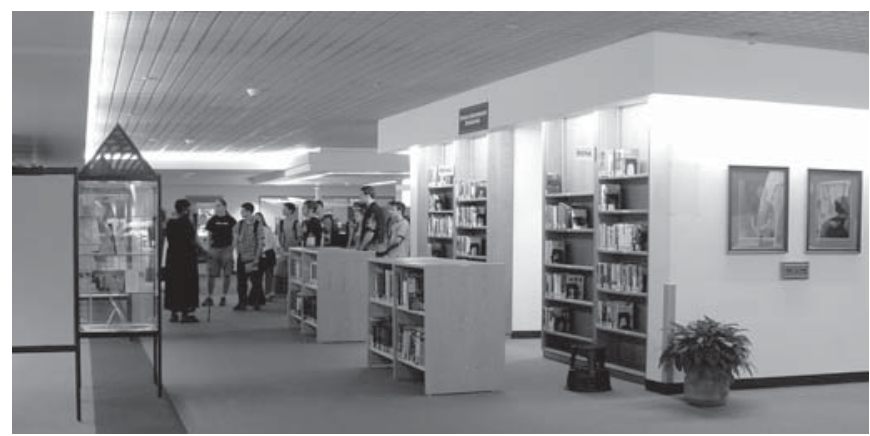

Rochester Institute of Technology Libraries

information sources," said Anne Campbell Moore, chair of the selection committee and assistant head of non-print management at Northeastern University Libraries. "The study will focus on how users view different resources and how different user and source characteristics influence the user's choices."

"This study couldn't come at a better time, as more and more users

constituencies. The result was an extensive reorganization that focused the organization on using cutting-edge technologies to bridge the library with faculty and students in innovative, highly effective ways. RIT is trying things that few other libraries have tried-and with excellent results."

Each winning library will receive $\$ 3,000$ and a plaque, to be presented at an award ceremony held on each recipient's campus. The winners also will receive special recognition at the ACRL President's Program during the ALA Annual Conference, Monday, June 26, 2006, at 1:30 p.m. in New Orleans.

\section{Kim wins 2006 ACRL Samuel Lazerow Fellowship}

Kyung-Sun Kim, of the University of Wisconsin-Madison, has been selected to receive the 2006 ACRL Samuel Lazerow Fellowship for Research in Technical Services or Acquisitions for her research proposal entitled, "Factors Affecting the Selection of Information Sources."

Sponsored by Thomson Scientific, the award fosters advances in collection devel-

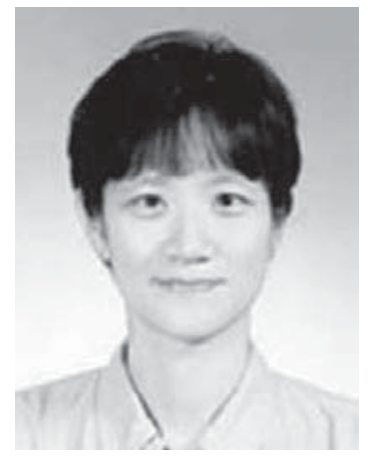

Kyung-Sun Kim opment and technical services by providing fellowships to librarians for travel or writing in those fields.

"Kyung-Sun Kim proposes to study user behavior in selecting and using different online choose to access information through means other than the library. Understanding the reasons users choose various sources to find information will prove invaluable in helping libraries decide how to allocate funds for collections and how best to deliver information sources. By identifying the characteristics of users and nonusers of particular resources, libraries will be better able to develop effective instructional programs directed at specific user populations."

The award of $\$ 1,000$ and a plaque will be presented during the ALA Annual Conference in New Orleans at the ACRL President's Program on Monday, June 26, at 1:30 p.m.

\section{Petrowski wins 2006 ACRL/IS Miriam Dudley Instruction Librarian Award}

Mary Jane Petrowski, ACRL associate director, is the winner of the ACRL Instruction Section's (IS) Miriam Dudley Instruction Librarian Award. The award honors Miriam Dudley, whose efforts in the field of information literacy lead to the formation of IS. The honor recognizes a librarian who has made a

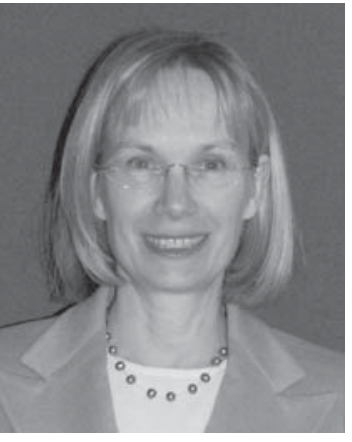
significant contribu-

Mary Jane Petrowski tion to the advancement of instruction in a college or research library environment.

"Ms. Petrowski is a nationally recognized leader in the profession, who has championed information literacy as a foundation for invigorating the librarians' teaching and 
learning roles," wrote Elizabeth Dupuis, chair of the IS Dudley award committee. "Of special significance is her extraordinary work to initiate the Institute for Information Literacy's Immersion Program. Selected as the first lead faculty of the Immersion Institute, she was charged with creating the curriculum, structuring the program, and developing a faculty cohort to support beginning instruction librarians and experienced instruction coordinators. She is credited with leading the six initial faculty members through the extensive process of curricular design through implementation for the first week-long Immersion Program in 1999. The resulting Immersion Program was a 'rich and substantial curriculum married to an active and intensive experiential learning model.' The Immersion Program is now in its seventh year, receiving accolades from attendees.

"Her vita evidences sustained contributions to professional organizations focused on the field of instruction," said Dupuis. "She is recognized internationally for her insights on information literacy, meriting an invitation to assist the academic instruction committee of the Australia Library Association with the development of their national Information Literacy Standards. She served on a number of committees and special task forces within the Instruction Section since 1990, including election as chair of the Instruction Section for 1998-1999. With her appointment in 2002 as associate director of ACRL, Ms. Petrowski continues her work within a premier professional organization, promoting and supporting the instructional role of libraries and librarians."

"Ms. Petrowski is frequently invited to speak at national and international conferences and possesses a distinguished record of contributions to books, reports, journals, and conference proceedings. She has served as a consultant for college, university, and military libraries, utilizing her experience to assist in establishing effective models at other institutions. Throughout her career, she has consistently looked beyond the field of librarianship for inspiration and relevance, and found applications for libraries. She has had a tremendous influence in the field of information literacy, both on practitioners and academic faculty."

In addition to her involvement with IS, Petrowski has been a member of ALA since 1979.

In 2000, she received the Faculty Innovation in Teaching Award from Colgate University. Petrowski is the coauthor, with Lizabeth Wilson, of the Research Guide: Introduction to Library Skills (1993).

Before coming to ACRL in 2002, Petrowski was head of information literacy at Case Library, Colgate University (1993-2002). She served at the University of Illinois at Urbana-Champaign as assistant undergraduate librarian in the Undergraduate Library (1989-93). Petrowski worked as reference librarian/cataloger at the U.S. Air Force Europe Command Library at Ramstein Air Base in West Germany (1986-88). Prior to that, she was the librarian for the United States Army Field Station Library in Sinop, Turkey (1978-85).

The award is sponsored by Elsevier Science on behalf of its journal Research Strategies. A check for $\$ 1,000$ and a plaque will be presented to Petrowski during the ALA Annual Conference in New Orleans during the IS Program on Sunday, June 25, at 1:30 p.m.

\section{Hugh C. Atkinson award winner announced}

Nancy M. Cline, Roy E. Larsen librarian of Harvard College at Harvard University, has been named the 2006 winner of the Hugh C. Atkinson Memorial Award. Cline will receive a cash award and a citation during the ALA Annual Conference in New Orleans, at the ACRL 
President's Program on Monday, June 26, 2006, at 1:30 p.m.

Named in honor of one of the pioneers of library automation, the Atkinson Award recognizes an academic librarian who has made significant contributions in the area of library automation or management, and has made notable improvements in library services or research.

"Nancy Cline is an exceptional leader," said Karen Williams, award committee chair. "She has the professional knowledge and capacity to think strategically and to help shape the future, rather than simply arrive there. She has helped to shape two premier research libraries at Harvard and Pennsylvania State University, and a number of professional organizations including the Association of Research Libraries, JSTOR, the Research Libraries Group, the Association of American Colleges and Universities, and the Digital Library Federation.

"Nancy combines an innovative spirit and an understanding of the power of technology to advance knowledge, teaching, and scholarship with a deep respect for the traditional values of libraries," said Williams. "She has demonstrated a joyous commitment to the challenges of librarianship, a practical acumen in getting things done, and a personal kindliness and steadfastness that has won her the liking and respect of all her peers."

"It is an honor to be identified by my colleagues for this award," said Cline. "Throughout my career I have been privileged to work with many people-in libraries, in other organizations, and in industry-who were willing to explore innovative directions and apply emerging technologies to forge stronger roles for libraries in teaching and research environments. I have especially enjoyed finding ways in which libraries can engage digital technologies and the power of information systems to provide access to the amazing legacy collections that reside in libraries and archives around the world. My hope is to inspire others in our field as Hugh Atkinson once inspired me: to think boldly, to challenge assumptions, and to not fear criticism."

Before becoming Roy E. Larsen librarian of Harvard College in 1996, Cline worked at Pennsylvania State University, where she served as dean of university libraries (198896), assistant dean and head of bibliographic resources and services division (1984-88), chief of the bibliographic resources department (1980-84), head of the government documents section (1971-80), and Pennsylvania documents librarian (1970-71).

The Hugh C. Atkinson Award is jointly sponsored by four ALA divisions: ACRL, the Association for Library Collections and Technical Services (ALCTS), the Library Administration and Management Association (LAMA), and the Library and Information Technology Association (LITA).

The award is funded from an endowment established to honor Hugh C. Atkinson. Donations to the endowment may be sent to Megan Bielefeld, 50 East Huron St., Chicago, IL 60611. 2

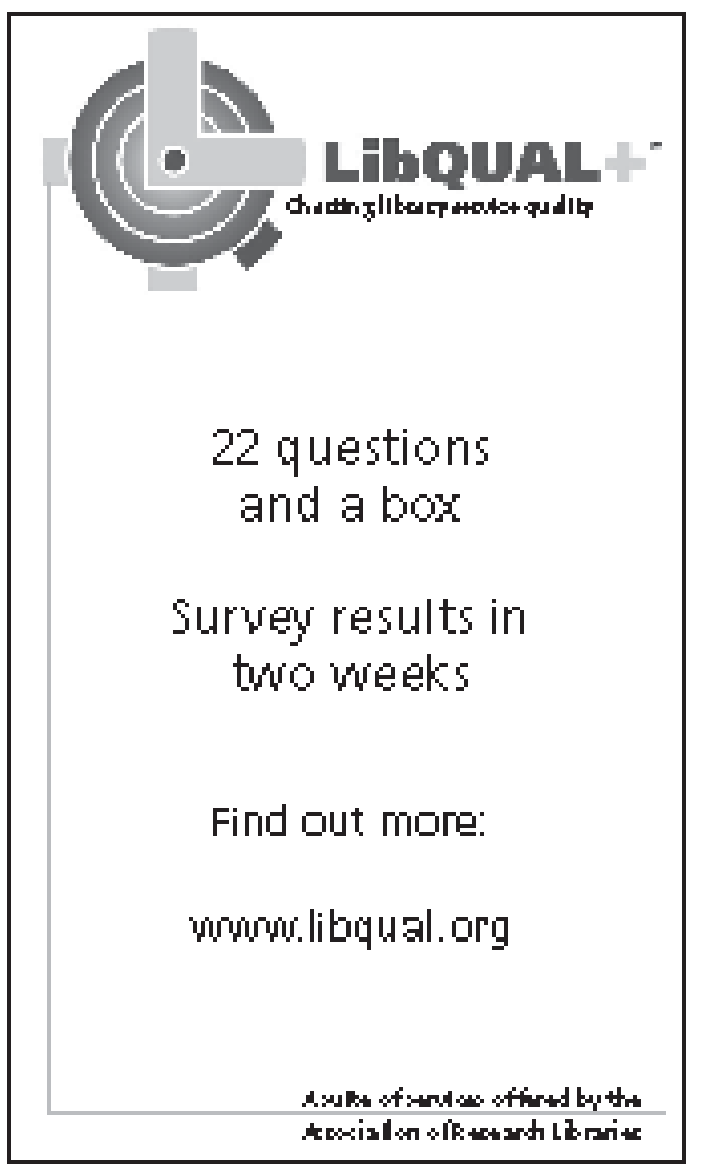

